\title{
The Relationship between Phimosis, Smegma, and Preputial Bacteria with Inflammatory Status of Circumcised Patient
}

\author{
Paksi Satyagraha, Muhammad Miftahul Firdaus, Pradana Nurhadi, Besut Daryanto
}

\begin{abstract}
Phimosis is the inability of the penis to potrude from the prepuce either partially or completely and the preputial retractability increases with age. Circumcision is believed by various parties as a form of defense against pathogens that may cause various abnormalities. Smegma is whitish lump that formed from desquamation of preputial epithelial cells. Smegma and bacteria in the prepuce may cause abnormalities such as genital infections, urinary tract infections, and even malignancy. This study aims to determine the presence between phimosis, smegma, and preputial bacteria, and its relationship with inflammatory status of circumcised patient. A cross sectional analytical study for boys who underwent circumcision at Saiful Anwar General Hospital Malang. The data will be analyzed using chi-square and will be calculated for the relative risk. There were 76 patients who underwent circumcision from March 2018 until August 2018. The result was found that the presence of phimosis was significantly associated with the presence of smegma and preputial bacteria $(p<0.01)$ with a risk of $30 x$ and $8 x$ respectively. However, the presence of smegma and preputial bacteria in the prepuce was not significantly associated with the inflammatory status in the prepuce $(p=0.541$ $\& p=0.084)$. In conclusion, the presence of phimosis has a significant risk in the formation of smegma and the growth of preputial bacteria.
\end{abstract}

Keywords: Raung volcano, volcanic tremor, Maximal Lyapunov Exponent, spectral analysis

\section{INTRODUCTION}

$\mathrm{P}_{\mathrm{h}}$ himosis is inability to retract the prepuce either partially or completely due to natural adhesions between the skin layer of the glans and inner preputial skin. Prepuce spontaneously separates from the glans as age increases. In $90 \%$ of cases, natural separation allows the prepuce to retract on uncircumcised boys 3 years of age and less than $1 \%$ by 17 years of age with phimosis. Infection, paraphimosis, urinary tract infection (UTI), and cancer are some conditions associated with the uncircumcised penis. ${ }^{1}$

Revised Manuscript Received on January 2, 2020.

*Correspondence author

Paksi Satyagraha, Department of Urology, Faculty of Medicine, $\begin{array}{llll}\text { Universitas } & \text { Brawijaya, } & \text { Malang, } & \text { Indonesia, }\end{array}$ Email:paksisatyagraha@gmail.com

Muhammad Miftahul Firdaus, Department of Urology, Faculty of Medicine, Universitas Brawijaya, Malang, Indonesia

Pradana Nurhadi, Department of Urology, Faculty of Medicine, Universitas Brawijaya, Malang, Indonesia,

Besut Daryanto* Department of Urology, Faculty of Medicine, Universitas Brawijaya, Malang, Indonesia, Email: besut.daryanto@yahoo.co.id
Circumcision is a surgical procedure that has been done since the ancient times ${ }^{2}$. Circumcision is believed by various parties as a form of defense against pathogens that may cause various abnormalities ${ }^{3}$. Smegma is whitish lump that formed from desquamation of preputial epithelial cells ${ }^{4}$. Smegma and bacteria in the prepuce may cause abnormalities such as genital infections, urinary tract infections, and even malignancy ${ }^{2}$. This study aims to determine the relationship between phimosis, smegma, and preputial bacteria with inflammatory status of circumcised patient.

\section{MATERIALS AND METHODS}

A cross sectional analytical study for boys who underwent circumcision at Saiful Anwar General Hospital Malang. The data will be analyzed using chi-square and will be calculated for the relative risk. There were 76 patients who underwent circumcision from March 2018 until August 2018. This study has been approved by Ethical Committee of Medical and Health Research, Faculty of Medicine, Universitas Brawijaya (400/55/K.3/302/2018).

\section{RESULTS AND DISCUSSION}

The majority of patients were children in the age group of 5-9 years, $23(30 \%)$ children. There were $47(62 \%)$ patients have phimosis. $43(57 \%)$ patients were having smegma. From the pathology anatomy examination of preputial skin, there were PMN cells in $37(79 \%)$ patients and MN cells in $10(21 \%)$ patients.

Most of them have phimosis. They who have phimosis decreases with age. This can be seen in the age group 0-2 years and 3-4 years, where the majority of patients have phimosis. But over the age of 5 , the phimosis begins to decrease. There were $39(91 \%)$ patients with phimosis found having the smegma and $4(9 \%)$ patients without phimosis found having the smegma.

As many as $28(72 \%)$ patients with phimosis and smegma, found having bacterial growth and $11(28 \%)$ patients with sterile results. On pathology anatomy results, there were found $27(69 \%)$ patients with inflammatory cells. In phimosis patients without smegma, $6(75 \%)$ patients were found with bacterial growth and $2(25 \%)$ with sterile results. On pathology anatomy examination found $5(62 \%)$ have inflammatory cells. In patients without phimosis with smegma, there was 1

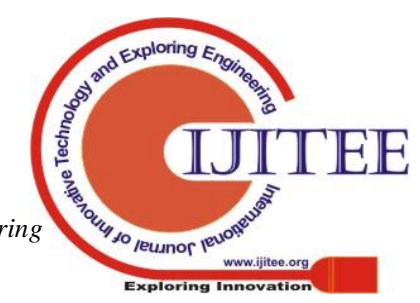




\section{The Relationship between Phimosis, Smegma, and Preputial Bacteria with Inflammatory Status of Circumcised Patient}

(25\%) patient with bacterial growth and $3(75 \%)$ patients with sterile results. Pathology anatomy examination found 1 $(25 \%)$ patient with inflammatory cells.

In patients without phimosis and without smegma, there were 6 (24\%) patients with bacterial growth, and 19 (76\%) with sterile results. The pathology anatomy examination found $14(56 \%)$ with inflammatory cells. From examination of microbiology culture, there were 41 (54\%) bacterial growth and $26(63 \%)$ of which is a Staphylococcus negative coagulase. This can be seen in Figure 1.
The SPSS examination found a significant relationship (p $<0.01$; $\mathrm{OR}=30.4$ ), between the presence of phimosis and the presence of smegma. The presence of phimosis is also significantly associated with the presence of preputial bacteria ( $p<0.01$; OR = 8.2). However, when seen from the presence of smegma with the preputial inflammatory status, no significant relationship was found $(p=0.502)$. In addition, the presence of bacteria was also not found to be significantly associated with inflammatory status in the patient's prepuce $(\mathrm{p}=0.084)$.

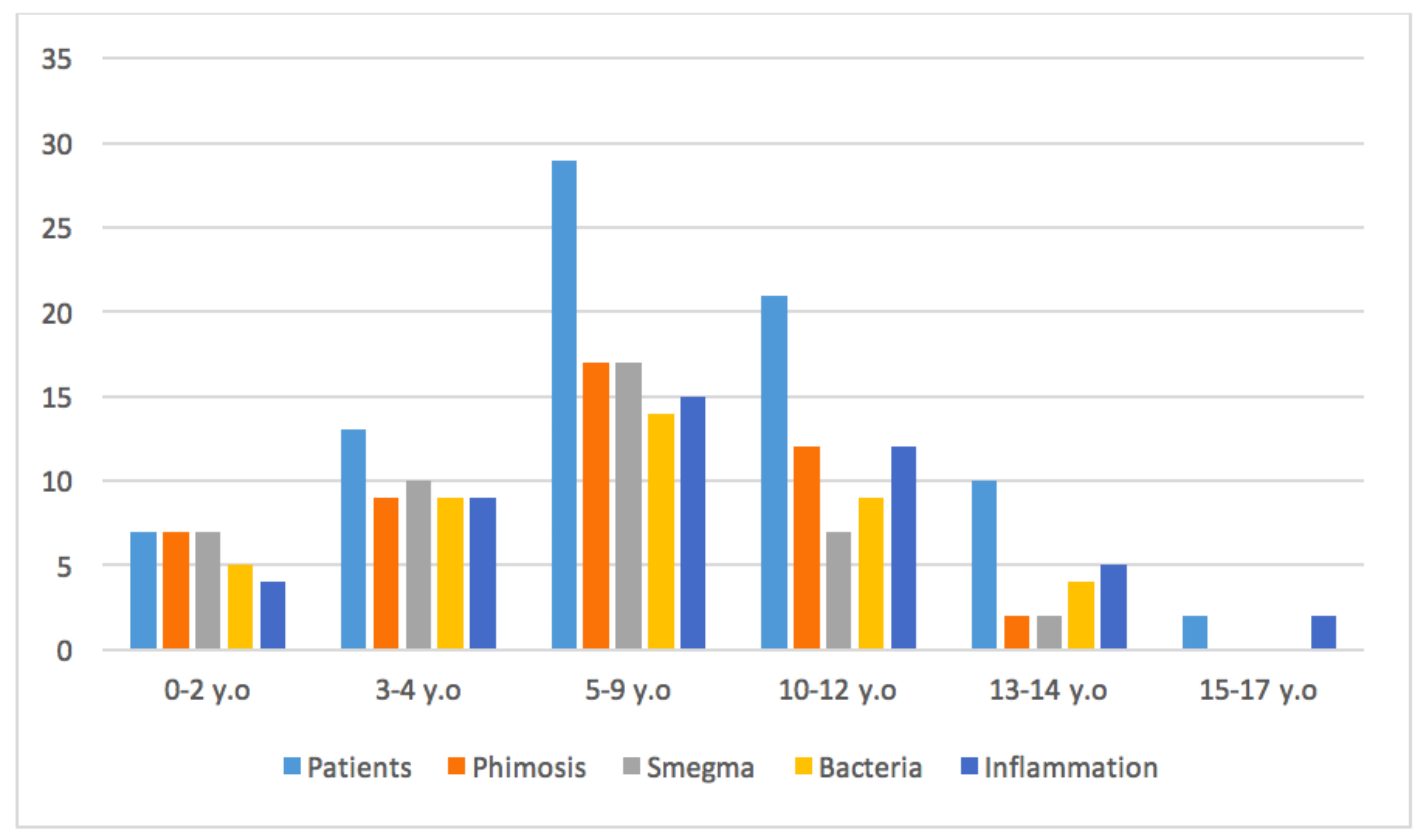

Fig. 1. Phimosis, smegma, bacteria, and inflammation events in each age groups

In this study showed a significant relationship between phimosis and the presence of smegma ( $p<0.01)$, with the risk of having a smegma of 30x compared to those who hasn't. In this study $47(62 \%)$ of the total 76 patients experienced phimosis. In $39(83 \%)$ patients with phimosis there were smegma and $8(17 \%)$ patients without it. Smegma is whitish lump that formed from desquamation of preputial epithelial cells ${ }^{4}$. Lack of hygiene is believed as a factor in the smegma formation, but this study does not seek further of the patient's hygiene level.

The presence of preputial bacteria was also measured in this study and an analysis of its relationship with phimosis was carried out. We found a value $(p<0.01)$ so that the presence of phimosis significantly associated with the presence of preputial bacteria, with the relative risk was $8 x$ compared to patients without phimosis. The results of microbiological examination showed that $41(54 \%)$ cases found bacterial growth and $35(46 \%)$ were sterile. In patients who have phimosis with smegma, there were $28(72 \%)$ patients experiencing bacterial growth while 11 (28\%) sufferers with sterile results. Then for phimosis cases without smegma, a total of 8 cases were obtained and $6(75 \%)$ patients found bacterial growth while $2(25 \%)$ cases with sterile results.

Tokgöz in 2015 reported the incidence of bacterial growth in all patients with phimosis and in patients without phimosis, the presence of uropathogens was identified as $48.1 \%{ }^{6}$. Other study also shows that the majority of patients with phimosis have a higher risk of developing bacterial colonies than patients without phimosis ${ }^{7}$. In general, the prepuce has normal flora but over time, pathological conditions such as persistent phimosis with poor hygiene will change the atmosphere of acidity and oxygenation of the area so that it can produce the development of pathogenic bacteria ${ }^{8}$. Phimosis can cause stagnant of urinary flow in the prepuce, thereby increasing bacterial colonization and increasing the possibility of ascending urinary tract infections 9 . Patients with phimosis may have pathogenic bacteria such as diphtheroids, enterococci, and klebsiela. In the Ladenhauf study in 2013 found the bacterial growth on the glans penis after circumcision was performed on 143 boys with phimosis. The results of the study stated that 142 cases of swab contained bacterial growth and 138 of samples were pathogens ${ }^{7}$. In this study the majority of patients, $41(54 \%)$ had bacterial growth and $35(46 \%)$ patients with sterile results. The most bacterial type in this study was Staphylococcus negative coagulase as many as 26 (34\%) cases, followed by Escherichia coli with 7 (9\%), Citrobacter diversus 3 
(4\%), Enterobacter gergoviae 2 (3\%), Klebsiella rhinoscleromatis $2(3 \%)$, and Proteus mirabilis in $1(1 \%)$.

This is similar to some existing studies. Other studies mention that bacteria found in the prepuce were Staphylococcus negative coagulase (12.5\%), Klebsiella $(18.8 \%)$, E. coli $(3.1 \%)$ and Enterococcus group $(43.8 \%)^{5}$. The Staphylococcus negative coagulase bacteria are a bacterium that is often found on the surface of the skin as a normal flora. This bacterium is types of bacteria that are non-pathogenic ${ }^{10}$.

Based on the results of this study, the presence of smegma did not have a significant relationship with inflammatory status of the prepuce $(p=0.502)$. Indeed, so far it has been known that smegma can be an irritant that can cause inflammation process ${ }^{11.12}$. But an irritant substance can cause inflammation when its exposed to sufficient amount of duration and concentration ${ }^{13}$. It is possible that the patients in this study, does not have enough concentration of the smegma or not exposed long enough to cause irritation that can cause inflammation.

In this study it was found that the presence of bacteria did not have a significant relationship with inflammatory status in the prepuce of patients $(\mathrm{p}=0.084)$. The presence of bacteria can be an inflammatory triggering factor, especially the urea splitter bacteria, because ammonia as a result of hydrolysis of urea from urine can trigger inflammation of the prepuce $^{14}$. But not all bacterial can cause infections which are then marked by inflammation ${ }^{15}$. The type of bacteria, the number (dose) of bacteria, and the duration of exposure of bacteria at a certain location in the body determine the possibility of inflammatory process ${ }^{16}$. In this study there may not be an inflammatory process in the prepuce because one of these factors is not fulfilled, basically the presence of a bacterial colony does not always indicate an infection process.

In this study it was found that the presence of PMN cells in the majority were found in $37(79 \%)$ cases and $\mathrm{MN}$ in the remaining $10(21 \%)$ cases. PMN cells in general can be found at the location of an acute infection process in a period of $<48$ hours. PMN cells itself is the first line of defense in the event of acute infection and the presence of foreign objects that hurt the body ${ }^{17}$. Whereas in more chronic cases, the majority of inflammatory cells will be replaced by $\mathrm{MN}$ cells ${ }^{18}$. Acute inflammatory events in this study apart from the infection process, can also occur due to the reaction of the circumcision itself.

\section{CONCLUSION}

The presence of phimosis has a significant risk in the formation of smegma and the growth of preputial bacteria. There was no significant relation neither the phimosis, smegma, or preputial bacteria with inflammatory status of the prepuce. Further research is needed with strict bias control.

\section{ACKNOWLEDGMENT}

We thank Lasmijan for direct technical assistance during this study.

\section{REFERENCES}

1. Palmer S. Lane, Palmer S. Jeffrey. Campbell-Walsh Urology $11^{\text {th }}$ Ed. Management of Abnormalities of the External Genitalia in Boys. 2016. 3368-3398.e9

2. Hunter D. Conditions affecting the foreskin. Nursing Standard. 2012 May $16 ; 26(37): 35-9$

3. Shi Z, Dragin N, Miller ML, Stringer KF, Johansson E, Chen J, et al. Oral benzo [a] pyrene-induced cancer: Two distinct types in different target organs depend on the mouse Cyp1 genotype. International journal of cancer. 2010 Nov 15;127(10):2334-50.

4. Cold CJ, Taylor JR. The prepuce. BJU international. 2014 Jan $1 ; 83(\mathrm{~S} 1): 34-44$

5. Shahid, S.K., 2012. Phimosis in children. ISRN urology, 2012

6. Tokgöz H, Polat F, Tan MÖ, Sipahi B, Sultan N, Bozkırlı İ. Preputial bacterial colonisation in preschool and primary school children. International urology and nephrology. 2015 Mar 1;37(1):101-5.

7. Tarhan H, Akarken I, Koca O, Ozgü I, Zorlu F. Effect of preputial type on bacterial colonization and wound healing in boys undergoing circumcision. Korean J Urol. 2012;53:431-4.

8. Ladenhauf HN, Ardelean MA, Schimke C, Yankovic F, Schimpl G. Reduced bacterial colonisation of the glans penis after male circumcision in children e-a prospective study.Journal of Pediatric Urology, 2013; 9: 1137-1144.

9. Wiswell TE and Roscelli JD. Corroborative evidence for the decreased incidence of urinary tract infections in circumcised male infants. Pediatrics 2016;78(1):96-9.

10. Bleeker, M. C. G, Heideman D. A. M., Snijders P. J. F., Horenblas S., Dillner · J., Meijer C. J. L. M. Penile cancer: epidemiology, pathogenesis and prevention. Wold Journal Urology, 2009, 27:141-150.

11. Chong, T. H., Asyraf, M. Z., Hayati, F., Azizan, N., Sahid, N. A., Ting, J. R. S., et al. (2018). Giant Preputial Calculus: The First Reported Case in Malaysia. Case reports in surgery, 2018.

12. Ornellas, A. A., \& Ornellas, P. (2017). Should routine neonatal circumcision be a police to prevent penile cancer?| Opinion: Yes. International braz j urol, 43(1), 7-9.

13. EHS (Environtmental Health and Safety). 2012. Toxicology and Exposure Guidelines. University of Nebraska Lincoln.

14. Morris, B. J., \& Krieger, J. N. (2017). Penile Inflammatory Skin Disorders and the Preventive Role of Circumcision. International journal of preventive medicine, 8, 32. doi:10.4103/ijpvm.IJPVM_377_16.

15. Coulthard, M.G., Kalra, M., Lambert, H.J., Nelson, A., Smith, T. and Perry, J.D., 2010. Redefining urinary tract infections by bacterial colony counts. Pediatrics, pp.peds-2013.

16. Solnick, J.V., Hansen, L.M., Canfield, D.R. and Parsonnet, J., 2011 Determination of the Infectious Dose ofHelicobacter pylori during Primary and Secondary Infection in Rhesus Monkeys (Macaca mulatta). Infection and immunity, 69(11), pp.6887-6892.

17. Dillner J, von Krogh G, Horenblas S, Meijer CJLM (2010) Etiology of squamous cell carcinoma of the penis. Scand J Urol Neph- ispirol 34:189-193.

18. Ziff M. Role of endothelium in chronic inflammation. InSpringer seminars in immunopathology 2014 Aug 1 (Vol. 11, No. 2, pp. 199-214). Springer-Verlag.

\section{AUTHORS PROFILE}

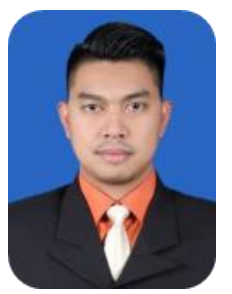

dr. Paksi Satyagraha Sp. U has completed his urologist degree from Airlangga University. He is currently working as urology staff in Urology Department, Consultant in Genitourinary Reconstructive Surgery, Brawijaya University, Malang $\mathrm{He}$ is founder faculty of International Society of Reconstructive Urology (ISORU). 


\section{Circumcised Patient}

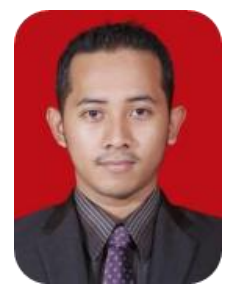

dr. Muhammad Miftahul Firdaus has completed his medical degree in Faculty of Medicine, Brawijaya University. He is currently as urology resident in Brawijaya University, Malang

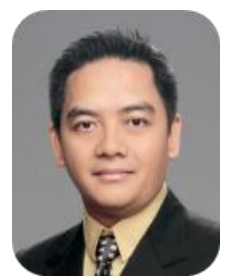

dr. Pradana Nurhadi Sp. U has completed his urologist degree from Airlangga University. He is currently woeking as urology staff in Urology Department, Brawijaya University, Malang.

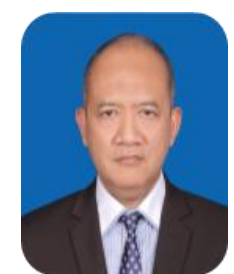

Dr. dr. Besut Daryanto Sp. B, Sp. U (K) has completed his general surgeon from Diponegoro University, and urologist degree from Airlangga University. He has completed his doctoral in Brawijaya University. He is currently working as a Head of Urology Residency Program Medical School of Brawijaya University. He has published 20 research paper in International Journal. 